\title{
強大台風ハイヤンに伴うヘルナニ町沿岸の浸水被害の調查
}

\section{Coastal Flood Disaster during Super Typhoon H aiyan in Hernani, Eastern Samar, Philippine}

\author{
信岡尚道 ${ }^{1} \cdot$ 安田誠宏 $^{2} \cdot$ 田島芳満 $^{3} \cdot$ 森 信人 ${ }^{4}$ \\ 下園武範 ${ }^{5} \cdot$ 佐々木 淳 $^{6} \cdot$ 过尾大樹 $^{7} \cdot$ KENNEDY Andrew $^{8} \cdot$ 宮本 守 $^{9}$ \\ Hisamichi NOBUOKA, Tomohiro YASUDA, Yoshimitsu TAJIMA, N obuhito M ORI \\ Takenori SHIM OZONO, J un SA SA KI, Daiki TSUJIO, A ndrew KEN NEDY and M amoru M IYAM OTO
}

\begin{abstract}
Super typhoon Haiyan/Yolanda in N ovember 2013 caused coastal flooding and severe damage in coastal zones not only in bays but also along open coastlines. In the Town of Hernani, located on the open Pacific coast of Eastern Samar province in the Philippines, the flooding and resulting washed-away houses were recorded in a widely-viewed video. This paper provides field survey results from Hernani including eyewitness accounts of inundation heights and time series profiles, measured ground levels and estimated sea bottom profiles, and measured dimensions of coastal dikes and of houses shown in the video. Information gathered here suggests that wave groups were the direct cause of coastal flooding in Hernani. Results in this paper will contribute to analysis of large wave disasters and flood prevention in open coastal zones.
\end{abstract}

\section{1はじめに}

2013年11月に最低中心気圧 $895 \mathrm{hPa}$ ，最大風速125knots (RSMC-TOKYOの10分間平均值；な㧊JWCOの1分間平均 值では170 knots）にまで及んだ非常に強大な台風Haiyan/ Yolanda（2013年台風30号）は，フィリピン中部を通過お よび上陸時にも勢力をさほど弱めなかった.

この台風によりフィリピンのレイテ州, サマール州や 東サマール州を取りかこむレイテ湾の奥にあるサンペド 口湾では $5 \mathrm{~m}$ を超える潮位偏差と8mほどにおよぶ痕跡高 を記録した（Tajima et.al, 2014)。全体の被害は2014年4月 17日時点で死者6300名, 行方不明者1061名, 負傷者 28689名, 被害総額が896億フィリピンペソとなった （NDRRM C，2014a）.さらには東サマール州の太平洋に面 した東側の海岸にある集落H ernani（ヘルナニ）などでも 壊滅的な被害が生じていたこのような台風における外洋 に面した居住地区の壊滅的な被害記録のうち自然科学的 に記したものは, 著者らの知る限り存在しない。した がって, 自然科学的記録を後世に残すこと，また防災・ 滅災対策のうち工学的に考慮すべき点を示すことは知見 の積み重ねの基礎として重要なものと考えられる.

\begin{tabular}{|c|c|c|}
\hline 1 正会員 & 博 (工) & 茨城大学准教授 工学部都市システム工学科 \\
\hline 2 正会員 & 博 (工) & 京都大学助教 防災研究所 \\
\hline 3 正会員 & $\mathrm{PhD}$ & 東京大学教授 大学院工学系研究科 \\
\hline 4 正会員 & 博 (工) & 京都大学准教授 防災研究所 \\
\hline 5 正会員 & 博 (工) & 東京大学講師 大学| \\
\hline 6 正会員 & 博 (工) & 授 大学院 \\
\hline 正会員 & 博 (工) & クコンサ \\
\hline & $\mathrm{PhD}$ & ne准教授 \\
\hline & 博 $($ 工 & 2 \\
\hline
\end{tabular}

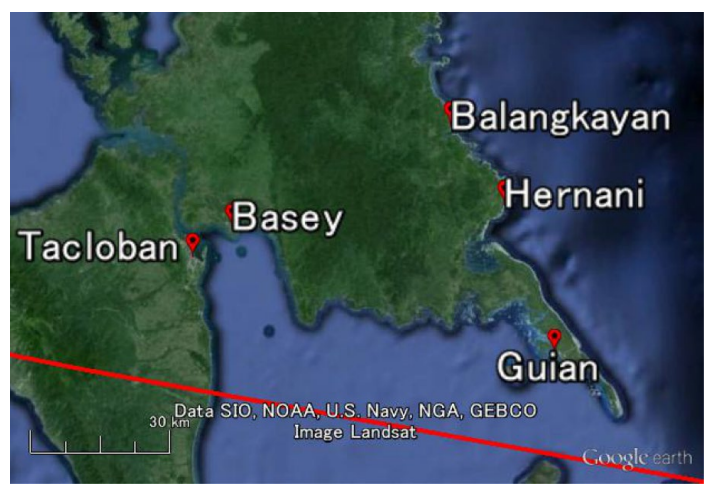

図-1 Haiyan経路と被災地マップ (赤線 ; 経路, RSMC - TOKYO)

本研究は, 台風Haiyanにより太平洋に面した居住地区 で被災した東サマール島のH ernaniの浸水状況について, 現地の痕跡高の測量調査およびヒアリング, ビデオ解析 した結果から自然科学的記録をまとめる. そして, 強大 台風に打いては高潮以外でも注意しなければならない浸 水被害を明らかにすること, その予測のベンチマークと なるデー夕を記すことを目的とする。

\section{Hernaniの地勢}

台風H aiyanは図-1に赤線で示すようにフィリピン中部 を横断する経路をたどった，Hernaniは東サマール州の中 ほどにあり, M atarinao湾の外で海岸線から南東に太平洋 を, また台風H aiyanの経路上の海面を見られるところに ある. Hernaniは13のバランガイ (最小行政区) で構成され ており（図-2)，人口は8070名（2010/3/1時点，Philippines Statistics A uthority), 主要産業は農業そして漁業となって 


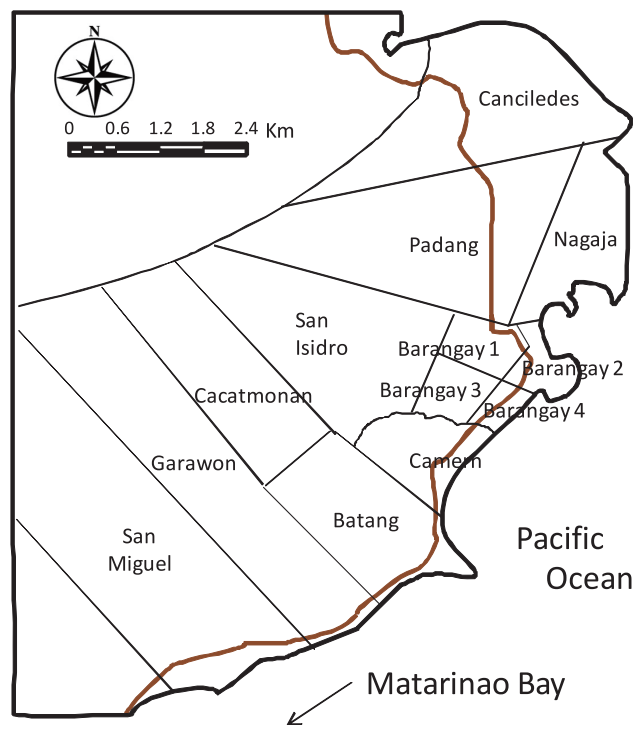

図-2 HernaniのBarangay概略地図

おり，フィリピンの中でも小さな集落と言えるところで ある. The M unicipality of HerinaniのWEBサイトには歴史 として，1897年10月12日に巨大なtidal wave がこの集落 を襲い，新しく建造された石づくりの教会を含む公共施 設が壊滅的な被害を受け, 300名以上の犠牲者が出た, この災害をうけて安全な場所に移住させた，と記されて いる.また，同災害についてはAlgue（1899）がまとめた 台風経路を含む写真と記録があり，フィリピン国の報道 機関のWEBサイトでも閲覧できる（GMA NEWS）。

\section{3. 被災調查方法}

H ernaniの現地調查は2013年12月13日（調査(1)1.5時間 11:00 12:30，(2) 0.5時間16:00～16:30)，2014年1月24日 (調查(3) 6時間: 09:30 16:00) と同26日（調查(4) 3時間: 14:00～17:00）の総計4回11時間抢こなった。調查(1) と (2) の間の時間はH ernaniより北上して最初の大きな浸水被害 があったBalangkayanの調査をおこなった. Hernani周辺 の災害復旧の遅れから, 調査(1)と(2)は往復7.0時間の Tacloban, 調查(3)と(4)の前後もTaclobanを, 調查(3)と(4)の 間は片道2時間のGuianを拠点としたが，その行程でも視 察などを㧍こなった。

調查(1)ではH ernaniのB arangay 4 (Pob.) で残存してい た3つの建物での, 痕跡高を海水面からのレベル測量調 查抢よび当時の状況のヒアリングを通訳を通して口頭で おこなった．調査(2)はH ernaniのB arangay 4 (Pob.) から 南西に移動したB arangay B atangにて，同様の調査をおこ なった。ここでの痕跡高には漂流物の高さも対象とした. なお，後で痕跡高の潮位補正を施した值を記録值とした。

調査(3)と(4)では痕跡高, 堤防高の追加調査とともに,

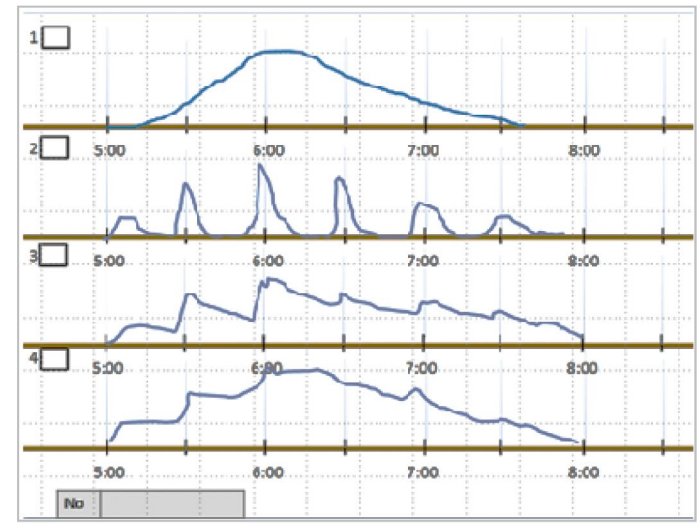

(a) 波形の選択

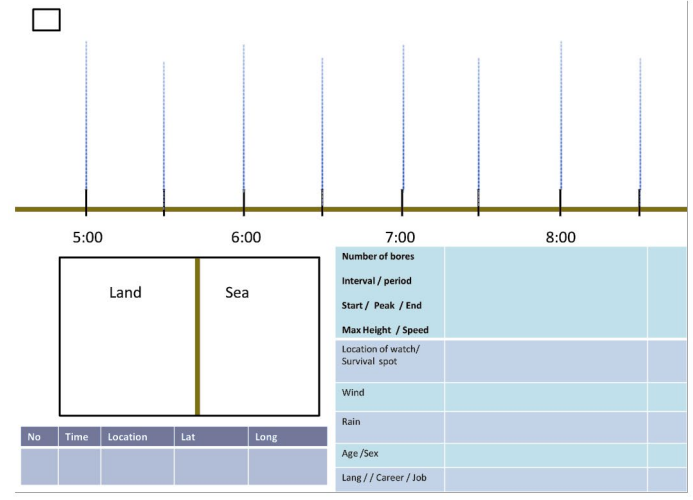

(b) 基本事項と波形の書きなおし用

図-3 ヒアリングトシート

海水の陸上遡上時のビデオ映像（Plan, 2013）の撮影場所 の特定と, そのビデオ映像拉よび水面の時系列変動の概 略図シート（図-3）を用いた当時の状況のヒアリングを 通訳を同伴して扔こなった，水面変動の概略図を用いた 理由は, 調查(1)と(2)に打いて今回の波を「Tsunami」と 表現するなど，現地では波に関する用語が定着していな かったためである，現地で海水が遡上してくるのを目撃 していた人に，証言の信頼性を調べる目的で，（i）まず 目撃した時間と場所を尋ね, 台風の通過時間と矛盾がな いか，また海水遡上時でも観察できる状態であったかを 確認した（ii）次に図-3（a）に示す4種類の時系列水面 変動（上からそれぞれ，高潮，高波，高波に高潮が加わ る，段波が主体を想定）から近い現象を選択してもらっ た（iii）つづいて, 浸水開始から最高水位に至る途中 で，一旦水が引いて地盤が見えたか確認をした．（iv）さ らに, 詳細な波形を尋ねていくことにして, 上昇時の波 の数を尋ねた，大きな波と小さな波については，先ほど の映像を見せて細かい水面の波は数えないようにした. ただし，映像約60秒で2回も大量の海水が遡上してきた のみなので, 風波か波群かを判断するための質問は連続 
した波の数と継続時間とした。（v）波のインターバルの 時間, 浸水開始から最高水位に至るまでの時間, 最高水 位で留まる時間，そこから海水が引いていく時間を確認 した.（vi）最後に, 海水が引く時の波形について確認し た。これらの質問の中で，横軸の時間や波形などは証言 者に確認を取りながら，手書きで修正を施していった。 このシートを用いたヒアリングは，比較のためGuianの 東海岸地区, レイテ湾奥のTaclobanとB asayでも実施した. 補足質問として風や雨の状況と, 遡上などが進行した方 向をたずね，さらに証言者の性別と推定年齢，英語が使 えるかどうかも確かめた.

調査(4)では，撮影場所，同映像の画角の特定と同画角 によるデジタル写真撮影, 映像に写り込んでいる家屋の 特定と寸法計測を，地形測量とともに実施した。

\section{Hernaniの被害記録}

台風H aiyanに伴うHernani全体の被害は2014年4月17日 時点で, 犠牲者72名, 行方不明者4名で負傷者197名と記 録されている (NDRRMC，2014b)．現地ではこの数に含 まれていない犠牲者がまだいると語る人が複数いた。 Barangay B atangでは約200軒の家のほぼすべてが流されて いて，その被災光景は東日本大震災を受けたいわき市薄

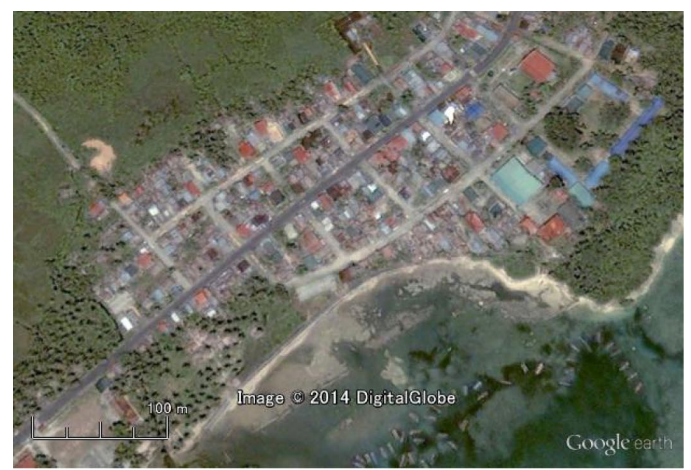

(a) 2008 年 8 月 24 日

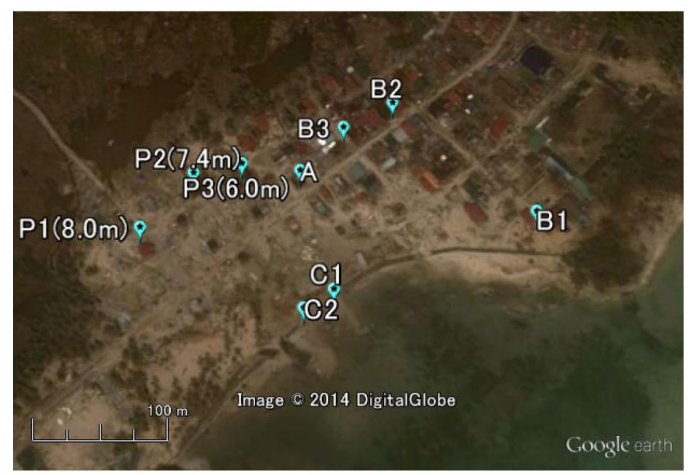

(b) 2013 年 11 月 11 日

図-4 B aragay 4 (Pob.), Hernaniの痕跡
磯地区と同等と思われた

\section{(1) 痕跡記録の詳細}

Hernaniの中心の一つB aragay 2 (Pob.), B arangay 4 （Pob.）の調查地点を図-4に示す，災害以前の衛星画像で ある図-4 (a) と比較すると災害後の図-4 (b) では集落 の南西部（図の中央から左下）でほとんどの家屋が流出 していることがわかる.P1〜P3点は痕跡高を測定した場 所であり，P1点の $8.0 \mathrm{~m} は$ 証言と建物の状況から波の成分 を含んだもの，P3点の $6.0 \mathrm{~m}$ は建物の内陸側の值でありこ こでは数十分程度は高さが継続したとの証言からも波の 成分は小さいと考えられたものである。

Hernaniの中で壊滅的な被害を受けたB arangay B atangの 調查地点を図-5に示す.P4点の痕跡高10.7mは，2Fの軒 先の下側に付着していた小さな草を対象に測量したもの であり，波の成分が含まれていると考えられる，P5点は 漂流物が小学校（B4点）の敷地につづく斜面で止まって いた6.6m, P6点は漂流物の最上端であり小学校の敷地と 同じ高さの $8.9 \mathrm{~m}$ である.この小学校には多数の住民が前 の晚から避難していたが, 水が迫ってきて危険と感じた ので，さらに高台へ避難したとの証言もある.

Hernaniから南西にM atarinao湾奥沿いに入ると浸水被害 は急激に減り，浸水高が低くなっていった，詳細は別途 報告するが，台風の経路はここょりもはるか南よりであ るので風向きの違いによる高潮の差とは考えられないこ とから，通常の高潮とは異なる分布と考えられた。また 逆にHernaniから北に沿岸沿いを移動していくと，しばら くは海沿いの集落でも被害は見られなく，次に大きな被 害を受けた集落は湾の奥を通りすぎたBalangkayanの Poblationで, Hernaniと同じような湾の入口近くで海岸線 が太平洋に面し，台風経路の方を向いていた.

\section{(2) 堤防および地形測量}

図-4（b）のC1とC2間の約30mは，写真-1のように破堤 して, 堤体材料のサンゴ礫とモルタルが現れていた。 写

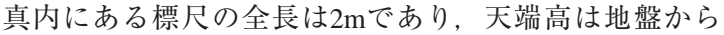
$1.8 \mathrm{~m}$ であった．写真の左奥に見える海水の部分も同様の

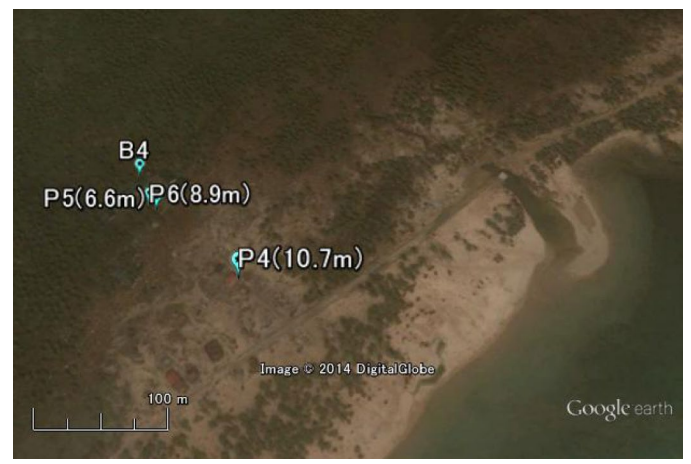

図-5 B aragay B atang, Hernaniの痕跡高 
破堤，写真の右側にも短い破堤区間があった．堤防前面

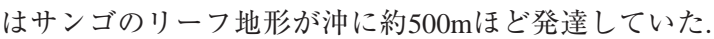
しばしばこのリーフに入水する住民が示した水深相当の 深さは60〜 $70 \mathrm{~cm}$ 程度であった。 これらの情報と水際か ら陸上のレベル測量をもとに作成した，Hernani Barangay 4 (Pob.) の断面図の概略を図-6に示す。海側は推定の高 さと距離である，陸側の高さ $6 \mathrm{~m}$ のラインは痕跡高調査で 示したP3点の高さである. 標高 $4 \mathrm{~m}$ 以上のところで浸水深 が $2 \mathrm{~m}$ あったとから，一部の破堤を勘案しても，堤防に よる浸水阻止は十分ではなかったと考えられる。

\section{（3）ビデオ映像からの推定高と推定速度}

写真-2はPIan（2013）で公開されているNickson Gensis 氏が撮影した映像からスクリーンスナップショットを 撮ったものである．撮影者と一緒にいた家主から，撮影 した場所が図-4 (b) のA点の家屋の2階空の平板ででき た水平格子の隙間からであったことを確認している。こ この地盤標高は4.8mである。映像は固定ではなく浸水に 合わせて移動しているので，浸水開始までの時間に限ら れるがほぼ同じ画角で撮影したものが写真-3である。写 真-3内の二つの家屋の各寸法を表-1に記す。それぞれの 寸法の区間は写真-2の左上とやや右寄り上で奥の方に移 り达んでいる．写真-2とこれらの情報から映像に映って いた遡上段波の1波目は，フロントの進行速度が2〜3 m/s で，短周期変動を除いた水面高さが $60 \mathrm{~cm}$ 程度であったと

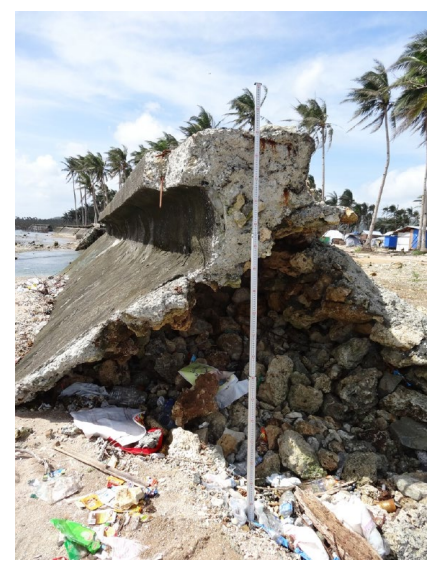

写真-1 Hernani Barangai4 (Pob.)の破堤

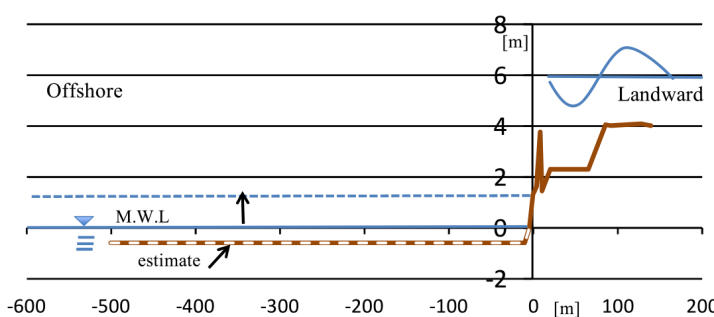

図-6 岸沖断面地形概略 (Hernani Barangay4 (Pob.))
推定された．映像の2波目は速さが先ほどの1.5倍で地盤 から $1 \mathrm{~m}$ 程度の水位に $1 \mathrm{~m}$ 程度の波が乗っていたと概算さ れた。 したがって，速さは長波相当と言える。また痕跡 高との比較から，映像の波よりも最大波はさらに大き かったとの証言を裏付ける結果とも言える.

\section{Hernaniにおける遡上水のヒアリング記録}

証言者の目視状況を総合すると, 強風で水面から水し

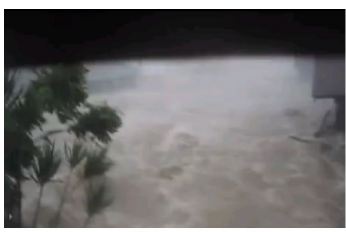

(a) 映像 $20 \mathrm{~s}$ 経過

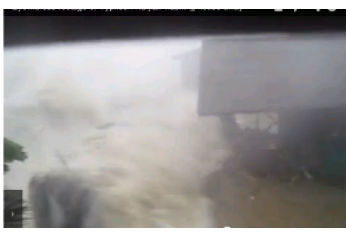

(b) 映像 $45 \mathrm{~s}$ 経過
写真-2 ビデオ映像

(出典; Plan (2013)，撮影M r. Nickson Gensis)

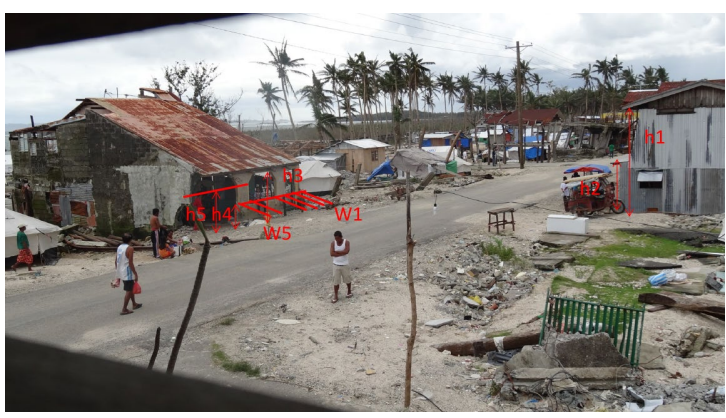

写真-3 撮影場所からほぼ同画角の画像

表-1 映像(写真-2)に関連する測量結果一覧

\begin{tabular}{|c|c|c|c|}
\hline No. & 測定対象 & 高さhor 幅w & 備考 \\
\hline h1 & 家屋の屋根下端 & $4.72 m$ & 2013/12/13以降改修 \\
\hline h2 & 家屋の1Fひさし & $2.37 \mathrm{~m}$ & 2013/12/13以降改修 \\
\hline h3 & 壁の空枠の上端 & $1.94 \mathrm{~m}$ & 2013/12/13と同様 \\
\hline h4 & 壁の空枠の下端 & $0.63 \mathrm{~m}$ & 2013/12/13と同様 \\
\hline h5 & 壁の空枠の幅変化 & & 2013/12/13と同様 \\
\hline w1 & 左端壁 & $0.32 \mathrm{~m}$ & \\
\hline w2 & 左端壁の右側隙間 & $0.84 \mathrm{~m}$ & \\
\hline w3 & 中間壁の右側 & $0.60 \mathrm{~m}$ & \\
\hline w4 & 空枠部 & $1.88 \mathrm{~m}$ & \\
\hline \multirow[t]{6}{*}{ w5 } & 中間壁の左側 & $0.66 \mathrm{~m}$ & \\
\hline & 流出家屋まで距離 & 約 $11.4 \mathrm{~m}$ & $\begin{array}{l}\text { 地盤のコンクリート } \\
\text { 部まで }\end{array}$ \\
\hline & 写真撮影高さ & 約 $3.5 \mathrm{~m}$ & 2014/1/26 撮影 \\
\hline & 映像撮影高さ & 推定3.3m & $\begin{array}{l}\text { 2013/11/8撮影by M r. } \\
\text { Nickson Gensis 場所 } \\
\text { は住人証言による }\end{array}$ \\
\hline & 家 (h1,h2) の幅 & 約6.6m & \\
\hline & 道幅（w1〜w5の前） & 約 $7 m$ & \\
\hline
\end{tabular}




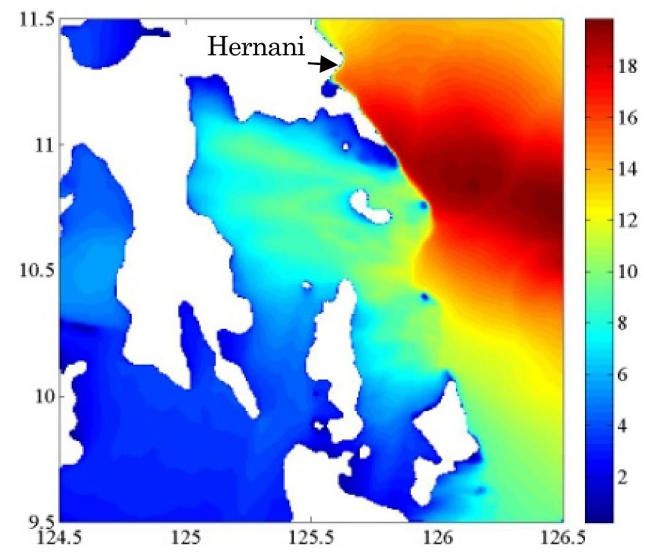

図-7 波浪追計算による最大有義波高分布 (縦軸：緯度, 横軸：経度, 波高単位 $[\mathrm{m}]$ )

ぶきがあがるので, 短距離の現象しか見えなかったと考 えるべきである，目視できた流れの方向は，その手前の 構造物に影響する。このような条件のもとであるが, 目 撃証言から陸上で3回程度の段波群が3分程度の周期で一 端低下もしくは地面が露出するまで降下した（5名中図-3 の選択肢2の回答のべ4名また選択肢3の回答のべ2名. 波 形はさらに短い周期で変動）と考えられた。 それらと記 録されていた映像が矛盾しなかった. TaclobanとBaseyで のヒアリングでは図-3の選択肢4が該当したので, Taclobanでの高潮（数十秒間で上昇する3段の段波）とは 異なる水位変化の現象がHernaniで起こったとも言える. また1件のみであったが, 警察官による前日の夜から浸 水に至るまでの約半日間の警戒中の証言内容は次のとお りであった. 11月8日の真夜中2:30頃から波が大きくなり 始め, 未明の4:30頃から越波が始まり, 5:00過ぎると海 岸線近くは危険な状態になり避難を開始した。強い波は 6:00〜 7:30くらいまで続いた. 浸水は, 陸にあがった海 水が引く前に次の波が来ることが繰り返されることで発 生した.

これらのことに, 周辺で被害にあった集落が台風進路 方向に開けた海岸のみであったことを合わせると次のこ とが推定される．高潮の上に外洋から入射してきた高波 浪が陸上奥深くまで遡上して, 排水される前に次の高波 がやってくることで, 海岸から数百離れたところでも 断続的に2時間程浸水することになった. 高波はリーフ 地形や砂浜 - 堤防で前傾化して段波形状となって家屋を 押し流したものと推定される。 なお, 計算方法の詳細は （森ら，2014）に譲るが，この台風により大きな高波が Hernani沿岸に来襲することは波浪追算で再現（図-7）で きている.

\section{6. 結論}

強大台風は湾奥に高潮偏差を主体とした被害をもたら す以外にも, 外洋に開いた海岸でも, 設計高を大きく上 回る高波浪を高潮偏差の上に来襲させ， L 2 津波による被 害に迫る被害をもたらす場合があることを示した。 Hernani町は地域の絆が大きく早めの避難の声かけによっ て犠牲者数が抑えられたが, 家屋や社会施設の被害は甚 大であったことを改めて強調しておく．この高波浪によ る浸水現象の数值再現を実施するためのデータも記した ことから, 本成果が強大台風による高波被害に関する想 定外を防ぎ，減災対策に活用されることを期待する.

謝辞：本調査は日本土木学会（JSCE）とフィリピン土木 学会 (PICE) の合同調査の成果の一部である. BENITO M.PACHECO，PICE前会長をはじめフィリピン土木学会 の方々から多大なる支援をいただいた。 また本調査の前 半は, (財) 河川環境管理財団より支援をいただいた. 調査の後半の一部は, JSPS科研費25303016（(B) 海外学 術調査, 代表：佐々木淳)，25350503（基盤研究 (C), 代表: 信岡尚道), および文部科学省気候変動リスク情 報創生プログラムの助成を受けてのものである.

\section{参 考 文 献}

森 信人 · 涉谷容子 - 竹見哲也 - 金 洙列 - 安田誠宏 $\cdot$ 丹羽竜 也・辻尾大樹・間瀬 肇（2014）：2013年台風30号H aiyan による高潮の予測可能性と再解析精度, 土木学会論文集 B2 (海岸工学), Vol.70, N o.2, 投稿中

Algue, P. Jose S.J. (1899) : "El Baguio de Samar y Leyte, 12-13 de Octubre de 1898”, M anila : J. M arty, 24p

GMA NEWS Online (2013) : http://www.gmanetwork.com/news/ story/336504/news/special reports/in-pictures-tales-of-woe-afterthe-leyte-samar-storm-surge-in-1897，(記事2013/11/21），参 照2014-05-20.

NDRRMC, National Disaster Risk Reduction and M anagement Council (2014a) : NDRRMC Updates re Effects of TY YOLANDA (HAIYAN) [17 A pril.], 参照2014-05-20.

NDRRM C, National Disaster Risk Reduction and M anagement Council (2014b) : Situation Report No.108 re Effects of Yolanda, 62P., http://www.ndrrmc.gov.ph/, 参照2014-05-20.

Philippines Statistics A uthority: http://www.census.gov.ph/,参照 2014-05-20.

Plan (2013) : http://plan-international.org/about-plan/resources/ videos /video-typhoon-washes-house-away, (M ovie was taken by M r. Nickson Gensis），参照2014-01-15.

The M unicipality of Hernani, http://www.hernani-esamar.gov.ph/, 参 照2014-05-20.

Tajima, Y., Yasuda, T. Pacheco, B. M., Cruz, E. C., Kawasaki, K., Nobuoka, H., M iyamoto, M., A sano, Y., A rikawa, T., Ortigas, N. M., A quino, R., M ata, W., Valdez, J. and Briones, F. (2014): Initial Report of JSCE-PICE Joint Survey on the Storm Surge Disaster Caused by Typhoon Haiyan, Coastal Engineering J ournal, Vol.56-01, DOI:10.1142/S0578563414500065. 